\title{
A produção de regras através de brincadeiras em um atendimento clínico comportamental infantil
}

\author{
The production of rules through playing in a child's behavioral clinical care \\ La producción de reglas a través de juegos en una atendencia clínica \\ conductual infantil
}

Tarita Almirão dos Santos Bezerra1, Ronaldo Rodrigues Teixeira Junior ${ }^{2}$, Diovani Cavalheiro Palha ${ }^{3}$

[1] [2] [3] Universidade Federal de Mato Grosso do Sul I Título abreviado: Produção de regras através de brincadeiras | Endereço para correspondência: Rua da Lapa, 382, Copamate, Campo Grande, Mato Grosso do Sul, CEP 79092-260. I Email: diovanihc@hotmail.com

\begin{abstract}
Resumo: Esse trabalho busca através do relato de um caso clínico infantil, demonstrar como brincadeiras e a produção de regras podem interferir em outros comportamentos de uma criança. $\mathrm{O}$ trabalho foi baseado nos registros dos atendimentos de Kissylla (nome fictício), de seis anos, que foi levada pela mãe à terapia. O caso tinha como queixa principal o roubo e a formulação do caso indicou que esse comportamento estava relacionado à dificuldades da cliente com relação ao seguimento generalizado de regras e questões a dificuldades no estabelecimento de vínculo afetivo com a mãe. As intervenções foram conduzidas através de brincadeiras e treino em sessão das situações problema com a criança e com a mãe e tinham como objetivo a formação de novas regras e aumento da proximidade entre mãe e filha. Inicialmente, a criança ganhava prêmios por seguir as regras das brincadeiras (reforço arbitrário), depois passou a ser mais controlada pela atenção da mãe (reforço natural). Após 41 sessões, observou-se a mudança em diversos operantes relacionados ao seguimento de regras, como por exemplo, não trapacear nos jogos e maior qualidade na interação com a família, tendo sido dada alta à cliente. $\mathrm{O}$ comportamento de roubar não foi foco do atendimento e deixou de ocorrer nos nove últimos meses da terapia.
\end{abstract}

Palavras-chave: Terapia comportamental infantil, roubo, regras, brincadeiras, estudo de caso 
Abstract: Using a children's case study report, this paper attempts to demonstrate how playing and the rule-making can interfere in other behavior of a child. The work was based on registers of the treatment of a six-year old child, Kissylla [a fictitious name], brought for therapy by her mother. The primary complain was related to stealing and the formulation of the case indicated that this behavior was related to difficulties of the child in following rules and in the establishment of affective relations with her mother. The interventions were carried out through playing and training sessions related to the problem situations between the child and her mother, with the objective of forming new rules and increasing the proximity between mother and daughter. Initially, the child was given gifts for following rules of games [arbitrary reinforcements]; then it passed on to be more controlled by the mother's attention [natural reinforcement]. After 41 sessions, changes were observed in different operant behaviors related to following rules, for example, not cheating during the games and greater quality of interaction with the family, leading to the patient's discharge. The theft behavior was not the focus of the treatment and did not occur during the last nine months of the therapy.

Keywords: child behavior therapy, stealing, rules, playing, case study.

Resumen: Este trabajo busca a través del relato de un caso clínico infantil demostrar como juegos y la producción de reglas puede interferir en otros comportamientos de un niño. El trabajo fue basado en los registros de las atendencias de Kissylla (nombre ficticio), que tenía seis años cuando fue llevada por su madre para hacer terapia. El caso tenía como principal queja los episodios de robo y la formulación del caso indicó que ese comportamiento estaba relacionado con dificultades de la cliente con el seguimiento generalizado de reglas y en el establecimiento de enlace afectivo con la madre. Las intervenciones fueran conducidas a través de juegos y de entrenamiento en las situaciones problema con la niña y su madre y tenían como meta la formación de nuevas reglas y aumento de proximidad entre madre e hija. En el inicio, la niña ganaba premios por seguir las reglas de los juegos (refuerzo arbitrario), después pasó a ser más controlada por la atención de la madre (refuerzo natural). Después de 41 sesiones, se observó el cambio en diversos operantes relacionados al seguimiento de reglas, como por ejemplo, no trapichear en los juegos y mayor calidad en la interacción con la familia, siendo concedida alta médica a la cliente. El comportamiento de robar no fue el foco de la atendencia y dejó de ocurrir en los nueve últimos meses de la terapia.

Palabras-clave: Terapia comportamental infantil, robo, reglas, juegos, estudio de caso. 
A psicoterapia comportamental infantil se consolidou como modelo de atendimento apenas na década de 50-60. Os primeiros trabalhos da área advêm de um momento da terapia comportamental chamado de modificação do comportamento e diferenciam-se do que hoje conhecemos por terapia analítico comportamental infantil - TACI (Conte \& Regra, 2000; Nico \& Thomaz, 2007; Regra, 2000). Um dos aspectos que distingue essa abordagem atual da anterior é a ênfase que antes era dada à aplicação de técnicas que pretendiam apenas eliminar ou adicionar respostas no repertório da criança, sem a preocupação com suas funções comportamentais e sem considerar a relação entre terapeuta e criança como parte do processo de mudança.

Assim, na modificação do comportamento, o terapeuta prepara a intervenção com base na observação dos comportamentos da criança fora da clínica e une os dados ao relato dos pais. Posterior a isso, os pais são informados verbalmente sobre como alterar os comportamentos dos filhos através da modificação de seus próprios comportamentos. A criança não participa do processo, no sentido de que não são ouvidas suas queixas e seus comportamentos privados não fazem parte da análise (Conte \& Regra, 2000). Além disso, muitas vezes, não há preocupação em adequar o ambiente de atendimento ao contexto infantil (Azevedo \& Moura, 2000).

McMahon (1996) atribui a forma como era feito o treinamento de pais (TP) nesse período como decorrente, dentre outros fatores, do avanço das técnicas de modificação do comportamento e do entendimento de que, sendo os problemas comportamentais derivados do ambiente, os pais constituem agentes significativos na mudança e manutenção dos comportamentos dos filhos. Conte e Regra (2000) colocam ainda, que esse entendimento da influência de variáveis ambientais no controle do comportamento levava à compreensão de que não se fazia necessária a intervenção direta com a criança.

Vale dizer ainda que a modificação do comportamento visava aplicar os métodos experimentais e tinha uma delimitação rigorosa, porém limitada, da tríplice contingência - antecedente, resposta, consequência (Conte \& Regra, 2000). Por esse motivo, a observação era feita, prioritariamente fora da clínica, e pode-se dizer que essa incompreensão derivou tanto da dificuldade de conciliar os métodos das ciências da natureza com os eventos privados, como do progresso dos estudos na época (Nico \& Thomaz, 2007). Segue-se a isso que as intervenções se davam em comportamentos isolados como forma de garantir o controle de variáveis. Apesar dos resultados rápidos, a falta de segurança na generalização e permanência dos resultados obtidos demonstrou a limitação dessa prática e isso tornou-se uma das principais críticas à modificação do comportamento (Guedes, 1993).

Ainda assim, apesar das críticas que a modificação do comportamento recebeu, Conte e Regra (2000) explicam que seu emprego foi importante para ajudar a conferir à Psicologia o status de ciência. Treinar pais, por exemplo, é ainda hoje aplicado na maioria dos problemas infantis, sendo que o objetivo do TP atualmente é habilitar os pais a realizarem análises funcionais, implementarem procedimentos de intervenção e generalizar e manter os ganhos obtidos, o que pode ser considerado uma resposta às críticas que antes eram direcionadas aos modificadores de comportamento (McMahon, 1996). Essa prática atual difere ainda da anterior, pois considera como elemento de análise o padrão de interação familiar, tanto dos pais com os filhos, como dos pais entre si e até mesmo dos pais com o terapeuta, bem como outras variáveis do contexto que podem dificultar a mudança de comportamento. Pode-se demonstrar então, a relevância que a interação ganhou no tratamento infantil, assim, na TACI os pais são muitas vezes atendidos junto com seus filhos, o que permite a observação da interação entre todos eles, bem como o treino de novas habilidades (Moura \& Venturelli, 2004). Outro procedimento ainda utilizado na TACI é o atendimento fora do consultório, porém, com o objetivo de complementar ou suplantar o relato verbal do atendimento clínico, além de buscar maior fidedignidade dos dados obtidos, justamente para que a intervenção seja mais eficiente (Borges \& Oliveira, 2007).

Ainda hoje técnicas similares àquelas inicialmente desenvolvidas pelos modificadores de comportamento são empregadas, porém avanços em pesquisas e a própria exigência clínica, alteraram tanto a forma de aplicação das técnicas, como também acrescentaram outras variáveis no conteúdo de análise. Por exemplo, a importância terapêutica do comportamento verbal é explicada na psicotera- 
pia analítica funcional (FAP) de Kohlenberg e Tsai (2001) que enfatiza outro fator até então excluído do processo terapêutico, a relação entre o terapeuta e o cliente. Um dos objetivos da psicoterapia analítica funcional é evocar comportamentos clinicamente relevantes (CRB), que são divididos pelos autores em: CRB1s, que se referem aos problemas vigentes do cliente que ocorrem na sessão e cuja frequência deveria reduzir ao longo da terapia; CRB2s, que se referem aos progressos do cliente que ocorrem durante a sessão e (CRB3s), que são as falas dos clientes sobre seus próprios comportamentos, incluindo interpretações a respeito de suas variáveis de controle ou descrições de relações funcionais acerca de seu próprio comportamento. Assim, tanto a relação terapêutica quanto o comportamento verbal passaram a ganhar importância e funcionar como um próprio meio de intervenção. Dessa forma, a análise do comportamento de ouvinte e falante, por exemplo, passou a ter grande importância clínica, já que a fala do cliente permite ao terapeuta acessar o ambiente público e privado da criança, além de auxiliar na produção do autoconhecimento, que é outra meta fundamental da terapia infantil (Conte \& Regra, 2000).

Kohlenberg e Tsai (2001) explicam como a fala do terapeuta pode evocar lembranças importantes para o processo terapêutico. $\mathrm{Na}$ terapia infantil, Nalin (1993) comenta um caso clínico em que o comportamento de fantasiar auxiliou o terapeuta a estabelecer relações e fazer hipóteses funcionais sobre comportamentos públicos e privados da criança. Porém, para identificar variáveis que controlam esses comportamentos no atendimento infantil, encontra-se o desafio, colocado por Regra (2000), de que a criança normalmente não elabora uma queixa ou, ainda, sua queixa difere daquela trazida por seus responsáveis.

A importância dos eventos privados pode ser vista em Azevedo e Moura (2000) que consideram a maior parte dos problemas comportamentais infantis, relacionados com a dificuldade em identificar e expressar sentimentos. As autoras colocam esse repertório como condição para a melhora das relações pessoais por seu envolvimento no desenvolvimento de outros comportamentos que auxiliam na adaptação social, no autocontrole e na formação de vínculos afetivos. Entretanto, no atendimento in- fantil, a abordagem direta pode não ser eficiente em conseguir o relato da criança sobre seus sentimentos e necessidades; por esse motivo, utiliza-se frequentemente histórias e fantasias como meio de obter descrições sobre o mundo privado da criança.

A brincadeira já era estudada por outras vertentes teóricas da Psicologia. Gil e de Rose (2003), no entanto, analisam que o maior destaque nessa área se deu na Psicologia do Desenvolvimento, possivelmente pela relação que o brincar criou com a própria condição de ser criança. Assim, encontrou-se a problemática de abordar a brincadeira do ponto de vista do desenvolvimento humano sem, no entanto, ser incoerente com o corpo teórico-conceitual da Análise do Comportamento. Relacionado a isso, os autores trazem então, a definição que Rosales-Ruiz e Baer (1997) propuseram do conceito chamado cunha comportamental, ou "behavioral cusp".

Para ser considerada uma cunha comportamental, uma habilidade aprendida deve alterar a relação entre o organismo e o seu ambiente de forma a permitir o contato com novas respostas, estímulos discriminativos ou consequências que estão além daquelas diretamente produzidas pelo novo comportamento. Assim, a cunha comportamental deve: expor o repertório individual a novos ambientes, especialmente novos reforçadores e punidores, novas contingências, novas respostas, novos controles de estímulos e novas comunidades de contingências de manutenção ou de extinção (Gil e de Rose, 2003, p. 386).

Dentro dessa definição, a brincadeira com parceiros pode ser considerada uma cunha comportamental, pois expõe a criança a uma série de combinações de instruções ${ }^{1}$, nas quais ela atua como ouvinte e falante, produzindo e seguindo outras instruções (de Rose \& Gil 2003). Os autores descrevem, por exemplo, um estudo feito por eles, que envolvia a observação de crianças brincando com blocos de madeira, sob a supervisão de uma professora. Observou-se que as instruções durante a brincadeira foram efetivas em ensinar para as crianças

1 Skinner (1966) define regras/instruções como estímulos especificadores de contingências que possuem uma função discriminativa, entretanto essa definição não é consensual entre os analistas do comportamento. Para Albuquerque (2001), por exemplo, regras podem exercer múltiplas funções. 
a sequência dos blocos, mas os autores observaram também que mais do que montar blocos, as crianças envolvidas nesse tipo de brincadeira também estavam aprendendo a seguir instruções cada vez mais complexas, já que essas eram recombinadas e refinadas conforme o desempenho da criança no jogo.

Assim como o conceito de cunha comportamental, o seguimento de instruções observado em muitos tipos de brincadeiras, também pode envolver outros conceitos complexos como o de classe de ordem superior. Caracterizam-se como classes de ordem superior, os operantes que não são definidos por relações específicas de estímulo e resposta, mas que se mantém pela correlação com outros membros da classe; em outras palavras, são aqueles operantes que emergiram sem a necessidade de passar por treino direto (Catania, 1999). Ou seja, não é necessário ser exposto a cada instrução para que se aprenda a seguir instruções de forma generalizada em brincadeiras ou em outros contextos.

Segundo Gil e de Rose (2003), durante a brincadeira, as crianças estão expostas a diversas formas de instruções e têm a possibilidade de aprender a segui-las, como também de formular novas instruções. A criança que tem um mínimo de repertório que permita brincar pode desenvolver e variar seu desempenho motor, cognitivo, afetivo, social e verbal. Na brincadeira, a criança entra em contato com contingências sociais criadas pelo grupo e por ela própria, tem a oportunidade de aprender padrões de comportamentos culturais.

Logo, as relações que compreendem a aprendizagem por instruções, podem ser criadas e alteradas através do brincar, e a brincadeira se torna também um meio de se obter dados sobre o comportamento da criança, além de estabelecer condições para a análise funcional, pois permite relacionar os eventos que ocorrem na sessão com as ações da criança. Assim, é um instrumento do terapeuta, participa do processo de avaliação e intervenção e pode ser utilizada na aquisição e alteração de comportamentos (Meyer \& Torres, 2003).

De forma geral, a literatura mostra como a interação entre pais e filhos, a brincadeira e o estabelecimento de regras podem interferir no comportamento de uma criança e auxiliar no atendimento clínico comportamental infantil (e.g., Borges \& Oliveira, 2007; Meyer \& Torres, 2003; Souza, 2007).
Sendo assim, o presente estudo tem como objetivo apresentar um relato de caso de aplicação de TACI em que foi realizada uma análise funcional do comportamento de roubar de uma criança. Serão descritos os prováveis efeitos de uma intervenção baseada em brincadeiras, que buscou estabelecer uma nova dinâmica na relação entre mãe e filha, favorecendo o seguimento generalizado de instruções e o fortalecimento do vínculo afetivo entre as duas.

\section{Método}

\section{Participantes}

Kissylla (nome fictício), seis anos de idade, sexo feminino, cursava a segunda série do ensino fundamental quando foi trazida ao atendimento por sua mãe, sob orientação da escola. Esta assinou o termo de consentimento livre e esclarecido, sendo informada da participação de sua filha nessa pesquisa ${ }^{2}$. Em algumas sessões também houve a participação da mãe e do irmão de Kissylla.

\section{Contexto}

O período de atendimento foi de 25 de novembro de 2011 até 20 de abril de 2013, totalizando 41 atendimentos, tendo sido realizado em uma das salas do ambulatório do hospital universitário de uma universidade pública.

Os atendimentos foram conduzidos pela primeira autora, aluna do curso de Psicologia, sob supervisão do professor da instituição, segundo autor e orientador deste trabalho. Todos os materiais adaptados ao ambiente infantil foram feitos pela estagiária, sob orientação do professor.

\section{Procedimento}

A ficha da cliente foi escolhida de forma aleatória pela autora, tendo iniciado os atendimentos de forma semanal. Todos os atendimentos passavam por supervisão, que consistia no relato verbal do caso pela estagiária e orientações do supervisor. As sessões tinham duração de 50 minutos, sendo que até a $8^{\text {a }}$ sessão, os 20 primeiros minutos do atendimen-

2 Projeto aprovado pelo Comitê de Ética em Pesquisa da Universidade Federal do Mato Grosso do Sul em 27/06/2013.

Número do Parecer: 320.377. 
to eram feitos com mãe e os 30 minutos restantes com a criança. A partir da $9^{a}$ sessão, os atendimentos passaram a ser intercalados, acontecendo um atendimento com a criança em uma semana e um atendimento com a mãe em outra, cada um com a duração de 50 minutos. No $22^{\circ}$ atendimento, as sessões passaram a ser em uma semana com a mãe e na outra com a mãe e a criança.

A partir da $30^{\text {a }}$ sessão, os atendimentos passaram a ser realizados de $15 \mathrm{em} 15$ dias e o irmão de Kissylla foi incluído nas sessões, nos dias em que a cliente e a mãe eram atendidas. A partir da $38^{\circ}$ sessão, as sessões foram feitas no intervalo de 30 dias, mantendo a alternância entre um atendimento com a mãe e outro com a mãe, a filha e o irmão. Além dos atendimentos convencionais, nesse período, foram feitas três visitas à casa da cliente com duração de uma hora cada, nas quais cliente, mãe e seu irmão estavam presentes.

\section{Registro}

O conteúdo de cada sessão era anotado pela estagiária com papel e caneta após o término de cada atendimento (não eram feitas anotações durante o atendimento). As anotações geravam um relatório semanal de aproximadamente três páginas elaborado pela estagiária, que era corrigido e arquivado pelo orientador. Os dados utilizados nesse trabalho foram extraídos desses registros. Não foram utilizadas gravações.

\section{Descrição do caso}

\section{Queixa e histórico familiar}

No início do atendimento, Kissylla tinha seis anos e morava com a mãe, os irmãos e o padrasto. Ela estudava no período matutino e no horário da tarde usava o tempo livre para ver TV e brincar com o irmão. Segundo a mãe, a menina apresentava comportamentos de roubar desde que tinha quatro anos e até o início do atendimento, ela já tinha roubado uma caixa de lápis de cor no mercado, uma boneca de uma amiga, um celular na casa da amiga da mãe, 150,00 reais de dentro de casa e uma moeda de um colega na escola.

A mãe disse que a direção escolar tinha orientado a procurar o atendimento devido à reação da menina ao ser pega roubando. Quando a escola pegou a criança com uma moeda de um colega, a menina disse que tinha ganhado da professora. Quando a professora disse que não havia dado, a cliente disse que havia achado no chão.

A mãe contou que a menina não demonstrava nenhuma alteração no seu comportamento quando roubava. Quando pegou a caixa de lápis de cor no mercado, a mãe soube porque o irmão mais velho viu e contou. Quando a mãe a pressionava a contar a verdade, a criança inventava histórias e depois chorava, então a mãe pedia para ela sair de perto dizendo que iria conversar depois, mas a menina, segundo a mãe, nunca admitia ter roubado.

A mãe dizia também que a cliente não tinha coleguinhas e quando ia buscá-la na escola, ela sempre estava sozinha; ela não dividia os brinquedos e não gostava de perder nas brincadeiras. Contou que na escola, certa vez, quando a professora insistiu para que ela dividisse o brinquedo com o qual estava, ela arrancou a cabeça da boneca e entregou à colega.

Ainda, segundo relato da mãe, a cliente não tinha medo de ninguém e "desafiava as pessoas com o olhar", ou seja, olhava fixamente quando alguém a contrariava. Em casa, a mãe dizia que a cliente não parava quieta quando não estava fazendo o que queria, deu exemplo de quando assistia TV e não era o canal que a cliente queria assistir, então ela começava a reclamar, falar alto, gritar, cantar. A mãe mandava que ela saísse do local caso não estivesse gostando do programa.

A mãe dizia ainda, que a cliente e o irmão brigavam o dia inteiro por qualquer coisa, principalmente por causa da escolha de canais na televisão e tempo para usar computador. Segundo a mãe, Kissylla não obedecia quando a mandava tomar banho ou arrumar o seu quarto, sendo que ela escondia os objetos no armário ou embaixo da cama para não arrumá-los. Na hora das refeições, não cortava os alimentos e ficava sem comer se a mãe não os cortasse para ela.

O padrasto de Kissylla trabalhava durante a noite e dormia durante o dia, o que segundo a mãe gerava problemas, pois Kissylla e o irmão brincavam durante o dia e faziam barulho enquanto ele dormia. A mãe dizia que pedia para que eles brincassem nos fundos ou na frente da casa, mas Kissylla não obedecia. 
Ainda segundo a mãe, a criança pedia muitas coisas, "o tempo todo e em todo lugar" e a frase que mais usava era "eu quero". Quando era contrariada batia a porta, quebrava coisas, resmungava e a mãe batia na criança e a deixava no quarto. Ela dizia que a criança era maldosa, pois quebrava objetos dos outros quando a pessoa não fazia algo que ela queria.

A mãe de Kissylla tinha 28 anos e, no início do atendimento, não trabalhava, passava a maior parte do tempo cuidando de afazeres domésticos e usando o computador. Teve seu primeiro filho aos 17 anos, Kissylla é a irmã do meio entre dois filhos homens, um de 11 anos e o outro de cinco meses. Ela é filha do segundo casamento de sua mãe e seu pai também já tinha um filho antes dela. $\mathrm{O}$ irmão mais velho de Kissylla apresentava comportamento de roubar desde a infância, havia feito psicoterapia, mas ainda mantinha esse comportamento. $\mathrm{Na}$ data do início do atendimento ele tinha 17 anos, morava com a avó paterna e ainda a roubava.

Os pais de Kissylla se separaram quando ela tinha dois anos, seu pai morreu quando ela tinha quatro anos. Ele era dependente de álcool e chegou a ficar internado em instituição para recuperação. A mãe disse que a causa da morte também se relacionava ao álcool e a criança já tinha presenciado cenas de violência do pai para com a mãe, mas o pai, segundo a mãe, nunca tinha sido violento com a filha. A mãe dizia que o pai sempre fazia as vontades da menina e que o padrasto também fazia isso. Ainda, segundo a mãe da cliente, quando o pai era vivo, a família morava ao lado do bar da avó paterna e o pai pedia à menina que pegasse dinheiro da avó dizendo que depois devolveria.

\section{Entrevistas iniciais (da $1^{\mathrm{a}}$ a $13^{\mathrm{a}}$ sessão)}

$\mathrm{Na}$ primeira sessão, a mãe foi acompanhada da cliente e, ao falar sobre a queixa abaixou a cabeça e não falou a palavra roubo. Disse que a filha pegava objetos, mudando a voz nesses momentos, o que a terapeuta considerou um tom infantil. Kissylla não se sentou, ficou andando pela sala de atendimento, mexeu na luz, no celular da mãe e colocou música. A mãe chamou a atenção em tom de voz baixo, pediu para que a criança parasse, mas ela continuou. Outro ponto observado foi que era um dia frio e Kissylla estava sem casaco e com voz rouca na tera- pia. Ao perguntar para a mãe o motivo, ela respondeu que a criança não quis colocar.

Em uma das sessões seguintes, a terapeuta observou ainda que um dia ao sair da terapia a criança pediu para que a mãe comprasse bala, a mãe respondeu que não. Então a menina pediu chiclete, a mãe respondeu novamente que não. A criança insistiu dizendo que então queria paçoca, a mãe disse "ê Kissylla, você e esses rituais", ela atravessou a rua e foi até o bar comprar a paçoca. Em outra sessão, foi perguntado à mãe quem ela tinha por modelo de pais. Ela ficou inicialmente em silêncio e depois respondeu que sempre quis ser diferente do que sua mãe foi, pois ela era muito rígida.

De forma geral, nas sessões iniciais, a mãe começava falando que Kissylla não obedecia, brigava com o irmão, que ela tinha "personalidade muito difícil". Quando questionada sobre como reagia ao comportamento da filha, a mãe voltava a falar do que a criança fazia. Quanto à cliente, essa chegava ao atendimento correndo, comendo doces e salgados, entrava na sala antes da terapeuta, ligava o ventilador, abria sua bolsa e tirava o que tinha dentro. Essas ações não foram inicialmente punidas pela terapeuta, pois o objetivo era o de observar CRBs, estabelecer audiência não-punitiva e formar vínculo com a criança.

As sessões iniciais foram conduzidas com brincadeiras não-dirigidas, histórias infantis, jogos que tinham por objetivo a interação com a cliente e a observação de seus comportamentos em situações que podia perder ou ganhar. Assim, durante as brincadeiras propostas, foi observado que quando perdia Kissylla tentava trapacear. Por exemplo, em um jogo de bingo, ela pediu para sortear as pedras e começou a tentar olhar os números de sua cartela, para então sorteá-los. No jogo de "Stop" ${ }^{3}$, tentava olhar a folha da terapeuta e quando perdia batia na mesa, reclamava e queria mudar de brincadeira. No fim das sessões, pedia para levar os brinquedos e quando explicado que não podia porque eles serviriam para brincar na terapia, a menina insistia dizendo que traria depois.

3 Jogo também conhecido como "adedânha", no qual se tem uma tabela de categorias em um papel dado a cada jogador (por exemplo, cidade, cores, animais, etc). O objetivo é ser o primeiro a preencher essas categorias de acordo com uma letra inicial sorteada e então dizer "stop". 
Outro exemplo relevante de comportamentos emitidos pela criança ocorreu durante uma atividade de desenho livre, na qual a cliente relatou gostar de brincar de polícia e ladrão. Ao ser questionada sobre quem gostava de ser na brincadeira a cliente respondeu que a polícia, pois ela prende o ladrão. A terapeuta deu continuidade perguntando se o que o ladrão fazia era certo ou errado e a cliente disse que era errado. Por último a terapeuta perguntou por que então será que o ladrão fazia isso e a criança respondeu que essa era uma boa pergunta. Posteriormente em atividade de completar sentenças na frase "eu gostaria de ser", a cliente escreveu "bonita". A mãe disse que a menina gostaria de ser branca e pintar os cabelos de amarelo, sendo que a criança e sua mãe são negras.

Além dessas atividades, foi levado também para a cliente o livro: "O primeiro livro da criança sobre psicoterapia”. Porém a cliente olhou para o livro, começou a bocejar e perguntou se a terapeuta iria ler o livro todo. A terapeuta respondeu que pretendia ler para explicar para ela o que era a terapia. A menina pegou o livro, disse para a terapeuta ler apenas até um ponto que ela marcou. A terapeuta começou a ler e a menina tomou o livro de sua mão e começou a ler, depois parou e mandou que a terapeuta continuasse a leitura, ela fez isso até o fim do livro.

Outras estratégias foram testadas até a $7^{\mathrm{a}}$ sessão como: apresentação de regras para cliente do que podia e o que não podia ser feito na terapia não mexer na bolsa da terapeuta, esperar chamar para entrar na sala de atendimento, uso de quadro e estrelas que eram trocadas por passeios, brinquedos e doces quando obedecia a mãe, e punição negativa para o comportamento de roubar (quando a menina roubasse seria retirado algo reforçador e ela deveria devolver o objeto roubado). No caso de seguimento de regras notaram-se algumas melhoras no comportamento da cliente, enquanto no caso do comportamento de roubar este não chegou a ocorrer e a estratégia foi suspensa com a mãe a pedido da terapeuta.

A partir da $9^{a}$ sessão houve a contratação do novo professor na instituição sendo que o orientador deste trabalho passou a assumir a supervisão do caso. Dessa forma, algumas análises e orientações para o atendimento foram reavaliadas e algumas informações foram colhidas através de novas entre- vistas, observações e brincadeiras nas três sessões seguintes. Além do seguimento de regras, viu-se a necessidade de se obter mais dados sobre a interação familiar. Diante disso, foi sugerida uma visita à casa da criança, o que foi permitido sem qualquer restrição de dia e horário pela mãe da cliente $^{4}$.

$\mathrm{Na} 13^{\mathrm{a}}$ sessão, quando a terapeuta chegou à casa de Kissylla, ela e seu irmão estavam brincando sozinhos e sua mãe estava dormindo. A menina abriu o portão e atravessou a rua correndo. Ela pegou a mala que a terapeuta levava com brinquedos e os retirou de dentro. A mãe já estava presente, mas não disse nada. O padrasto também estava em casa, mas saiu do quarto depois de meia hora, não cumprimentou a terapeuta e saiu também sem se despedir. Foi observado ainda que a cozinha da casa não tinha mesa, foi perguntado à mãe onde eram feitas as refeições e a mãe disse que no sofá, em frente à televisão.

Em um momento da visita foi proposta uma brincadeira com bola. Em dado instante ,a bola caiu para fora da casa, a menina pulou o muro e saiu correndo atrás. A mãe não se direcionou e nem falou com a criança, virou-se e disse para a terapeuta "esta é uma briga minha com a Kissylla, ela nunca olha para atravessar". Depois da primeira brincadeira com a família, a mãe fez pipoca e chá e levou para todos. O filho de um ano segurou a bacia e começou a jogar pipoca no chão, a mãe tentou tirar a bacia da sua mão, ele resmungou e a mãe tentou tirar novamente puxando de sua mão, tentou dar pipoca para ele colocando em sua boca, como ele não largou a bacia, ela a retirou e disse que então o menino não iria comer. Para o irmão mais velho, a mãe também retirou a bacia de sua mão e disse que ele estava gordo e que não era para comer mais. $\mathrm{O}$ menino respondeu para a mãe: "Você está magrinha?” e a mãe disse que sim. A mãe interagia com as crianças como observado na clínica, em tom de voz que a terapeuta entendeu como infantil.

Em outro momento, enquanto a terapeuta brincava com as crianças, o irmão mais velho colocou um vídeo para mostrar seu tio por parte de mãe.

4 A partir desse momento, passou-se a atender em uma semana a criança e na outra somente a mãe com o objetivo de trabalhar também suas dificuldades já que interferiam no comportamento da cliente de seguir regras 
Ele disse: "meu tio tem 30 anos, minha mãe tem 29. Quem você acha que parece mais velho?" A mãe respondeu: "Ele é a minha cara, só que ele nasceu de dia e eu nasci de noite" (fazendo alusão ao fato de o irmão ser branco). Situações de ironia similares entre a família já tinham sido observadas nas sessões, como quando a terapeuta perguntava sobre como tinha sido a semana e a mãe dizia à cliente "conta para sua psicóloga como você foi comportada”. Quanto à hora de comer, Kissylla dizia que não queria comer para não ser gorda como a sua mãe. Em outro momento, a mãe levou o irmão mais novo de Kissylla na terapia e a terapeuta comentou a semelhança dele com a cliente, então a mãe disse "coitadinho".

$\mathrm{Na}$ hora de ir embora, os irmãos de Kyssylla começaram a ajudar a guardar os brinquedos, enquanto a cliente começou a brincar fora da casa. Então, a mãe gritou: "Kissylla. você não está se esquecendo de nada?” Depois que a mãe chamou umas três vezes, Kissylla voltou e ajudou a guardar. Um pouco antes de a terapeuta sair, a mãe disse para a cliente: "Você não vai mostrar para a sua psicóloga o seu quarto tão arrumadinho?" A menina segurou na mão da terapeuta e foi mostrar o quarto, que não estava arrumado.

\section{Análise funcional (da 14 a $18^{\mathrm{a}}$ sessão)}

A apresentação da formulação do caso foi feita com a mãe, explicando que o nosso comportamento é produto de uma história passada e também do que vivemos no presente. Cada item foi relacionado com os comportamentos da cliente observados e relatados. Por exemplo, nas queixas principais, o não seguimento de regras foi explicado para a mãe que ao falar com a filha ela usava tom de voz irônico, pedia de forma indireta o que dificultava o cumprimento da regra por parte da criança. Por exemplo, em sua casa, ao invés de pedir para que a menina ajudasse a guardar os brinquedos a mãe perguntou se ela não tinha se esquecido de nada.

A mãe também cedia às chantagens da filha, reforçando-a de forma intermitente, como quando a menina pediu paçoca e mãe disse que não, mas depois fez o que a menina queria. Isso porque a mãe era reforçada negativamente ao fazer as vontades da filha pela retirada momentânea de estímulos aversivos, como a insistência da menina. Ao mesmo tempo condicionava o não-seguimento de regras por parte da criança, que sempre tentava negociar frente a limites, apresentando variabilidade comportamental nesses contextos como: chorar, gritar, quebrar coisas, bater portas, encarar os adultos quando contrariada.

Foram explicados também os dados relevantes da história, como o pai mandar a menina roubar a avó, dando esse modelo de comportamento à criança, tal como o irmão por parte de pai que apresentava os mesmos comportamentos de roubo indicando a presença de fatores comuns no ambiente que favoreceu o aparecimento e a manutenção desses repertórios. $\mathrm{O}$ fato de a criança ter presenciado cenas de violência do pai para com a mãe, também dava um modelo de agressividade, enquanto a mãe apresentava padrão de passividade/agressividade, demonstrado na dificuldade que ela tinha em dizer não à criança e em colocar limites, muitas vezes batendo na criança.

A função da mãe bater e gritar com a menina também foi explicada por reforço negativo. Porém, na menina tais comportamentos da mãe aumentavam a probabilidade da criança mentir como forma de se esquivar de apanhar. Também foi colocada a dificuldade da mãe em elogiar e interagir com os filhos de forma assertiva, sendo que esta fazia brincadeiras agressivas como chamar o filho de gordo ou dizer que o bebê era coitado por se parecer com a irmã. A terapeuta explicou a definição de passividade, agressividade e assertividade, já que também foi observado, que a mãe tinha dificuldades de tomar decisões como o horário da terapia ou ver se a filha precisava vestir um casaco em um dia frio. Ainda foi conversado a respeito da autoestima ${ }^{5} \mathrm{da}$ criança em função da mãe fazer brincadeiras sobre sua cor, como no dia da visita em que a mãe faz alusão ao fato do irmão ser "branco como o dia" e ela "escura como a noite" e o fato da menina não se achar bonita e se desenhar loira com olhos claros.

A explicação da formulação foi finalizada explicando que o foco do atendimento não era o roubo, mas sim o seguimento de regras pela criança e a firmeza da mãe ao colocar limites. Foi analisado que

5 Guilhardi (2002) define autoestima como um tipo de sentimento, produto de contingências de reforçamento positivo de origem social. 
não apenas o comportamento de roubar da criança, como seus outros comportamentos de desobediência, ocorriam principalmente em função de regras frágeis pela mãe, que tinha dificuldade em estabelecê-las e fornecer conseqüências para seu não seguimento. Somado a isso, o a ambiente familiar se mostrou carente de reforçadores sociais, o que não promovia uma relação satisfatória de afeto e respeito entre mãe e filha, contribuindo para a continuidade dos problemas apresentados. Uma hipótese então formulada é que trabalhando esses dois aspectos, regras e relação familiar, isto faria com que os comportamentos de roubo e desobediência da filha diminuíssem de freqüência. Para atingir esses objetivos, viu-se como necessário a construção de uma rotina mais organizada na casa com regras bem estabelecidas e mais momentos de carinho e brincadeiras entre a mãe e filha de forma a reforçar também a autoestima da cliente.

\section{Intervenções (da 19a a 30 ${ }^{\mathrm{a}}$ sessão)}

Em uma das primeiras sessões de intervenção, foi decidido que o primeiro aspecto a ser trabalhado nas sessões seria referente à autoestima da criança. Isso seria feito inicialmente através de brincadeiras com a terapeuta, que tinham como objetivo fornecer reforçadores positivos sociais visando a valorização dos sentimentos da cliente ser quem ela é (nome, cabelo, cor, etc) e não apenas os comportamentos que emite. Devido ao fato de ter um nome incomum e poder ter dificuldades na escola com os colegas devido a isso, a terapeuta iniciou o atendimento escrevendo no quadro da sala de atendimento "Boa tarde Kissylla!" A criança entrou na sala e disse "Você escreveu meu nome direitinho!" A terapeuta respondeu "Você acha que não presto atenção em você?! Você já escreveu seu nome para mim." Então, Kissylla diz "Mas, você escreveu meu nome direitinho." Ao longo dessa sessão, a criança pediu para brincar no quadro, então ela escreveu seu nome outra vez, mas desenhou uma menina de cabelos amarelos e olhos verdes dizendo que era ela (CRB1).

Na sessão seguinte, foram levadas pela terapeuta fotos e a biografias de pessoas negras famosas, com o objetivo de dar modelos de pessoas da cor da cliente que são consideradas bonitas ou bem sucedidas. Assim, foram levados materiais das se- guintes pessoas: Taís Araújo, Lázaro Ramos, Pelé, Daiane dos Santos, Naomi Campbell, Glória Maria. Antes de começar a falar sobre os personagens levados, a cliente disse "você vai contar a história de todos eles?” (CRB1). Depois de contar a história de cada personagem, foi proposto à Kissylla que escolhesse os que ela gostou mais para colar em uma cartolina. Ela escolheu o Pelé, a Naomi Campbell, a Daiane dos Santos e a Glória Maria. A cliente colou esses personagens em sua cartolina e desenhou novamente uma menina loira com os olhos verdes (CRB1). A terapeuta também fez um cartaz com os personagens que sobraram, então desenhou uma menina negra com cabelos cacheados, com a roupa que a cliente estava no dia. Quando a cliente viu, ela disse: "Sou eu!" A terapeuta respondeu: "Você gostou? Você é bem mais bonita do que isso, mas não sou boa em desenhos." A cliente disse: "Você é muito boa, você sabe desenhar muito bem." No fim, a cliente perguntou se o tempo estava acabando e se podia desenhar no quadro uma surpresa para sua mãe. A terapeuta disse que sim, então Kissylla desenhou nuvens e passarinhos e pediu à terapeuta que a desenhasse igual tinha feito em sua cartolina, ou seja, negra com cabelos cacheados (CRB2).

Em outra sessão, preparada com o mesmo objetivo, foi elaborada a brincadeira de salão de beleza. Assim, o ambiente foi preparado com espelho, escova de cabelo, presilhas, maquiagens e foi montada uma revista com fotos apenas de mulheres negras. A cliente, que estava com o cabelo amarrado, puxado para trás e com bastante creme para deixá-lo mais liso, escolheu um modelo de cabelo na revista e pediu para que a terapeuta o fizesse. A terapeuta desamarrou o cabelo da cliente e foi deixando bastante cacheado e com volume. A cliente saiu da cadeira onde estava sendo arrumada e desfilou pela sala, depois pediu para fazer o mesmo com o cabelo da terapeuta. Ela pegou os bobs, colocou no cabelo da terapeuta e disse: "vamos fingir que está enrolado." Pediu também para chamar a mãe, que ficou um pouco sem graça, mas fez o mesmo em seu cabelo com os bobs.

Após essas etapas iniciais de intervenção, foi decidido realizar uma segunda visita à casa da cliente, agora com o objetivo de estabelecer uma nova rotina de brincadeiras e regras para todos da família. Assim, primeiro foi feita uma sessão com a 
mãe para esclarecer esse objetivo e ver se ela estava de acordo com as intervenções. Vídeos da Super Nanny do Brasil foram utilizados com a mãe da cliente para dar alguns exemplos de como agir em situações similares em sua casa.

No $1^{\circ}$ vídeo (SBT do Brasil, 2010a), a mãe refere-se à menina como "probleminha da casa", ela grita, chuta, bate as coisas caso não dê o que ela quer na hora em que ela pede. As crianças ficam brincando livremente enquanto a mãe está no computador. Começa o vídeo a mãe mexendo no computador, sem dar atenção às crianças e depois perde a paciência e bate. Os pais falam com a filha de forma agressiva e a menina também se comporta de forma agressiva. A partir disso, foi relacionado o caso do vídeo com o caso da cliente dizendo que quando, por exemplo, a mãe chama o seu filho de gordo está sendo agressiva e que assim ela também dá o mesmo modelo para ele. A mãe da cliente enche os olhos de lágrimas e diz: "Às vezes faço coisas sem noção, a gente acha que criança não se magoa." No $2^{\circ}$ vídeo (SBT do Brasil, 2010b), foram feitas as observações de que a mãe não explica as coisas para as crianças, não conversa, somente pune quando desobedecem. Isso foi relacionado com quando a mãe da cliente desligava a TV quando os irmãos estão brigando, sem, no entanto, conversar, explicar e tentar resolver. Foi dito à mãe da cliente que isso era ser agressivo e não firme e que formas de punição como o bater não deveriam mais ser empregadas. Foi então explicado à mãe tudo que foi planejado pela terapeuta para ser realizado na próxima visita à cliente, sendo que a mãe ajudou a terapeuta na elaboração das regras da casa que considerava mais importantes de serem estabelecidas.

Assim, a próxima sessão ocorreu na casa da cliente. Foram levadas as regras que foram fixadas no corredor da casa junto com a mãe e as crianças. Quando cumprissem as regras as crianças ganhariam uma estrela e ao fim do dia quem tivesse ao menos uma estrela andaria uma casa em um caminho feito para cada um, quem tivesse mais estrelas andaria duas casas. Ao fim do caminho, as crianças escolheriam um prêmio que poderia ser: um passeio, mais tempo na TV ou no computador. Caso não cumprissem a regra, após terem sido avisados, ficariam no cantinho da disciplina de forma similar ao modelo apresentado nos vídeos da Super Nanny, o qual foi representado por um quadro em um canto da cozinha. A criança ficaria lá pelo tempo correspondente a sua idade em minutos (por exemplo, 6 anos - 6 minutos) e ao sair diria por que foi para lá e pediria desculpas. Além disso, foi fixada uma rotina que também foi construída junto com a mãe na terapia.

Durante toda a explicação sobre as regras e a rotina, Kissylla argumentou. Quando a terapeuta terminou a explicação e disse que iria embora, Kissylla disse para a mãe: "Mas, a gente vai começar a fazer depois das férias não é?" (CRB1). A mãe diz "Não, nós vamos começar agora!" (CRB2). Porém na primeira sessão que ocorreu depois de duas semanas, correspondente ao período de férias da Instituição, a mãe de Kissylla disse que não tinha feito o combinado, pois o irmão de Kissylla havia passado as férias na avó e Kissylla disse para a mãe que não dava para fazer sem ele. Contou também que deu um tapa na menina por ela não ter obedecido e se levantado para ir à escola. Então, a terapeuta disse para ela que Kissylla já não estava querendo fazer no dia da apresentação, mas que a mãe naquela ocasião havia sido firme com ela e isso tinha sido positivo, porém depois novamente deixou-se levar pelas manipulações da criança. Além disso, a mãe não usou o cantinho da disciplina e voltou a bater na criança, o que não devia mais acontecer. Foi sinalizado para ela que a menina não a obedecia, pois ela ainda não dava atenção nos momentos corretos e cedia às vontades da criança condicionando um padrão de desobediência.

Como as sessões estavam sendo feitas uma com a mãe e outra com a criança, com a mãe era trabalhado ela conseguir interagir, brincar com os filhos e também saber colocar regras, e com a cliente, a aprendizagem do seguimento de regras e formação de autorregras. Assim, para trabalhar a produção de regras com a criança foram feitas, pela terapeuta, duas histórias infantis. A primeira história foi do gato de botas, de como ele roubava e sentia-se mal por isso, mas foi ajudado por seus amigos e ficou feliz com a companhia deles. A outra história falava do tio patinhas e dos irmãos metralha, mostrando como o tio patinhas seguia os conselhos de sua família e se divertia com eles, enquanto os irmãos metralha acabavam tristes por ouvirem conselhos de pessoas que não queriam o seu bem. Após ter- 
minar de ler a história, a terapeuta propôs fazer uma história junto com Kissylla, a cliente então respondeu: "Você não trouxe outra coisa?" (CRB1). A terapeuta respondeu que não, mas que faria com ela a história e ela iria ver como seria legal. Kissylla disse que achava que seria difícil e a terapeuta disse que iria ajudá-la. Ela fez então, uma história sobre Bob Esponja.

O seguimento de regras também foi trabalhado em um jogo de boliche entre a terapeuta e a cliente, no qual ao derrubar um pino a pessoa retirava de dentro de um pote um papel que continha diversas regras. As regras, feitas pela terapeuta, relacionavam-se às dificuldades que a cliente ainda apresentava, segundo o relato da mãe, como tomar banho sem chorar, ser empática com as outras pessoas, pedir licença, não pedir excessivamente para que a mãe comprasse coisas, entre outros. Por exemplo, uma das regras foi "O seu quarto estava todo bagunçado, sem que sua mãe pedisse você o arrumou e encontrou um brinquedo que você gostava muito, mas não sabia onde estava. Ganhe mais um ponto." Depois de ler a regra a cliente conta que isso já aconteceu com ela. A terapeuta perguntou o que ela achou e ela disse "bem legal", pois tinha encontrado um brinquedo perdido.

No início do jogo a terapeuta estava ganhando e a cliente disse: "Ah, você vai ganhar!" (CRB1). Porém, depois ela mesma falou "lembra da regrinha, quem perde continua jogando, porque o importante é brincar" (CRB2). Essa regra não foi dita diretamente para a criança, mas ela passou a emitir, após a leitura de um dos livros nas fases iniciais do atendimento que falava sobre a importância de não desistir. Em outro momento do jogo a terapeuta começa a perder e a cliente pega a bola e diz que vai ensiná-la a fazer um "strike" (CRB2). Quando as regras elaboradas pela terapeuta acabaram, ela sugeriu para a cliente que elas criassem outras regras para continuar a brincadeira. Ao dar continuidade ao jogo, a cliente retirou uma regra elaborada por ela mesma: "Você roubou cinco reais de uma pessoa e escondeu da sua mãe. Fique cinco rodadas sem jogar e da próxima vez devolva." A cliente então, senta-se à mesa e permanece quieta durante as cinco rodadas que ficou sem jogar. Todas as regras elaboradas pela cliente se relacionavam com o tema dinheiro. No final da sessão, Kissylla queria conti- nuar jogando mas a terapeuta explicou que o tempo tinha acabado. Kissylla insistiu: "só mais uma jogada" (CRB1). A terapeuta respondeu: "lembre-se que precisamos obedecer algumas regras, semana que vem brincamos de novo".

Nos atendimentos com a mãe, ela ainda relatava dificuldades em cumprir a regras e a rotina estabelecida com a terapeuta para sua casa. Quando questionada sobre sua maior dificuldade, ela respondeu que era interagir com os filhos. Assim, foi entendido como importante trabalhar melhor a relação familiar dentro da sessão ${ }^{6}$. No primeiro atendimento com a mãe e a filha, a terapeuta levou o jogo do ludo, no qual algumas casas eram marcadas e quando o pião parasse em uma dessas casas elas retirariam uma sentença feita pela terapeuta. A mãe então retirou uma sentença assim: "Sua filha cuidou do irmãozinho. Encene como você a elogiaria e poderá andar três casas." A mãe ficou por volta de dois minutos sem conseguir falar nada. Depois falou em tom de brincadeira "minha filha eu te amo. Parabéns." Esse episódio demonstrou a dificuldade que a mãe tinha em elogiar a filha, conforme ela mesma já havia relatado.

A última sentença tirada pela mãe foi: "Sua filha saiu com uma amiga. A amiga lhe contou que ela roubou dois reais. Quando chegou a sua casa ela não lhe contou nada. Encene como você agiria nessa situação." A mãe olhou para a menina e disse: "Você tem alguma coisa para me contar?" A menina disse que não. A mãe disse: "tem certeza? Não aconteceu nada?" A menina disse que não. A mãe então disse: "mas, sua amiga me disse que você roubou dois reais". A menina respondeu: "eu achei no chão". A mãe disse: "mas você não viu ninguém procurando pelo dinheiro?" A menina disse que não. A mãe respondeu: "mas sua amiga disse que foi você". A menina respondeu que devolveu. A mãe perguntou: "que horas?" A menina respondeu que não tinha celular para saber as horas. A mãe respondeu que já tinha falado isso com ela. A menina começa a dizer que quer ir ao banheiro. Então, a terapeuta pede que ela aguarde, pois está terminando a sessão. A mãe diz que é isso que acontece. No momento em que a mãe falava com a criança, a

6 A partir da $22^{\text {a }}$ sessão passou-se a fazer um atendimento somente com a mãe e o outro com a mãe e a criança 
menina encara a mãe, conforme ela havia relatado do início do atendimento.

A fala da mãe e a da criança são CRBs 1, a mãe pela falta de habilidade em falar de forma assertiva, direta e a menina pela esquiva, inventando mentiras e pedindo para ir ao banheiro. A terapeuta então encenou com a criança como a mãe poderia falar nessas situações. A terapeuta disse para a criança "Kissylla eu sei que você roubou este dinheiro e eu já te disse e sei que você sabe que isso é errado. Eu fico triste quando você faz isso, pois você é uma boa menina, mas isso que você fez é errado e você não deve fazer mais, você me entendeu?" A menina disse que sim e não encara a terapeuta como fez com a mãe.

Com o mesmo objetivo de treino das situações que a mãe relatava dificuldades, foi feita a brincadeira da batata-quente, em quem parasse a bola o outro escolheria algo que gostaria de treinar. A mãe começou e pediu para encenar arrumar o quarto. Então ela diz para Kissylla: "Filha, arruma o seu quarto." Kissylla diz "tá bom”, mas encena continuar brincando no quarto. Então ela vira e diz para a terapeuta: "Daí ela já vem com o cinto." A terapeuta pergunta quando foi a última vez que ela bateu na filha. A mãe respondeu que foi semana anterior quando saiu e mandou Kissylla tomar banho, mas quando voltou ela estava brincando. A terapeuta pede que encenem como foi e ao final ao invés de bater encenem o uso do cantinho da disciplina. Elas o fazem e no final a mãe pede desculpas por ter batido na criança, ela diz "desculpa minha filha, por ter batido em você. A mamãe não queria ter feito isso, ta bom? Você me desculpa?" a menina diz que sim e abraça a mãe.

Assim, no $25^{\circ}$ atendimento foi perguntado à mãe sua avaliação sobre o atendimento até aquele momento. Ela responde: "Bom, você me ajudou a perceber que sou eu mesma, é a minha vida toda bagunçada que faz a Kissylla se comportar assim. Antes eu achava que era ela e pronto, que ela estava errada e eu não fazia nada. Eu criei uma barreira entre meus filhos e eu, pois como tive filho nova, achei que eu não podia mais ser criança $e$ me obriguei a amadurecer. Achei que eu devia ser mãe: lavar, passar, limpar. Quando eles me chamavam para brincar eu dizia que estava muito velha para isso."
Apesar disso, a mãe ainda relatava dificuldade em se organizar com a rotina e ter tempo para brincar com os filhos. Segundo ela mesma, conseguia um dia e não conseguia outro, porém a terapeuta buscou deixá-la mais sensível ao que ela já tinha conquistado como brincar às vezes com seus filhos. Ao fim desse mesmo atendimento, por exemplo, a mãe contou que comprou um tabuleiro de damas para jogar com as crianças e que planejou um passeio no domingo para ir à piscina. Buscou-se reforçar os pequenos ganhos que a família tinha ao longo das sessões, aumentando a discriminação da mãe sobre o que tinha conseguido fazer.

Finalmente na $27^{\mathrm{a}}$ sessão, a mãe relatou pela primeira vez ter conseguido usar o cantinho da disciplina como alternativa ao bater. Ela diz ter feito, pois Kissylla desrespeitou o padrasto o imitando quando este lhe deu uma ordem. Pergunto como Kissylla reagiu e a mãe diz que ela chorou e depois pediu desculpas pelo que fez ao padrasto. Avaliando como positivos os resultados das sessões anteriores, foram usadas novamente variações de jogos que envolviam sentenças para refinar esses comportamentos da mãe e da filha. Durante um deles, Kissylla retirou duas frases. A primeira dizia: "Diga uma coisa que você gostou e uma que não gostou nas regras de sua casa." Então, ela respondeu: "Gostei da família brincar junto. Não gostei de tomar banho." O segundo dizia: "Diga um comportamento da sua mãe que você gostaria que ela mudasse. Fale com carinho e respeito, assim sua mãe terá mais chance de fazer o que você quer, além disso, ganhará a chance de jogar mais uma vez!" Kissylla respondeu: "Eu gostaria que quando você fosse me mandar tomar banho, você não gritasse." A mãe concorda, diz que irá procurar não fazer mais e elas se abraçam.

A mãe de Kissylla também retirou dois bilhetes. O primeiro: "O que mudou em sua casa e no relacionamento com seus filhos após a terapia? O que você acha que ainda precisa melhorar?" A mãe respondeu: "Eu consigo entender melhor eles e me controlar para não gritar e não bater. Eu percebo que o ambiente familiar influencia em como eles estão se comportando, acho que precisa melhorar eu conseguir cumprir as regras mesmo." O segundo bilhete foi: "Diga à sua filha como você se sente quando ela mente para você. Explique de forma firme, mas respeitosa como você gostaria que ela 
se comportasse." A mãe diz: "Eu fico muito triste quando você mente para mim porque eu gostaria que você confiasse em mim e não ficasse pensando se eu vou ficar brava ou não. Eu quero que você confie em mim e conte o que acontecer de agora em diante, tá?" (CRB 2).

No atendimento seguinte, foi elaborado um jogo de tabuleiro que a terapeuta chamou de jogo da família ${ }^{7}$. O jogo foi feito com o objetivo de treinar as situações em que a mãe ainda encontrava dificuldade em colocar regras para a filha. No jogo, a mãe de Kissylla caiu em uma casinha em que tinha que dizer aos participantes uma coisa na qual eles precisavam melhorar. Então, ela disse à Kissylla "no banho, porque você sempre espera eu falar." A terapeuta pede que encenem a hora do banho. A mãe iniciou dizendo: "que horas são?" Kissylla respondeu "não sei”. A mãe continuou: “16:30", então Kissylla encenou que foi tomar banho. Através desta cena se observou que a mãe ainda tinha dificuldades em falar de forma direta e carinhosa com a filha, a terapeuta deu um modelo encenando com a cliente outra forma de pedir para a menina tomar banho e pediu que elas repetissem a encenação.

Em outra jogada, a mãe de Kissylla jogou novamente e caiu em uma casa que dizia: "você desobedeceu às regras. Fique uma rodada sem jogar no cantinho da disciplina." Essa frase tinha por objetivo treinar com a mãe o uso do cantinho, já que ela tinha feito apenas uma vez. Assim que a mãe tirou essa opção, Kissylla disse "eu nunca fiquei no cantinho da disciplina." Como a mãe havia relatado na sessão anterior que tinha colocado a menina no cantinho, a terapeuta perguntou para a criança se ela não tinha ido, na semana passada. Então, a mãe diz para a menina "o que você fez?". Kissylla respondeu que não lembrava e a mãe disse: "você ficou retrucando seu padrasto." A terapeuta pediu que elas encenassem como aconteceu. Elas mostraram conforme a mãe tinha descrito na semana anterior, Kissylla ficou parecendo que iria chorar. Depois que encenou, a terapeuta perguntou à clien-

7 Jogo de tabuleiro elaborado pela terapeuta, no qual cada casa continha uma proposição de treino das dificuldades apresentadas, como a hora do banho. Possuía também casas com carta bônus com sentenças diversas para cumprir entre os membros da família, por exemplo, contar uma história. te o que ela havia pensado no cantinho, e ela disse "tem que respeitar as pessoas".

Kissylla continuou jogando e retirou uma carta que dizia "diga algo que você gostaria que sua mãe melhorasse". Ela respondeu: "a família brincar junto", e disse que é porque a mãe não está querendo brincar às vezes. A mãe respondeu que precisa brincar mais vezes, pois não está brincando todos os dias. Isso já era algo que a mãe trazia nas sessões quando era atendida sozinha e, juntamente com outras informações confirmadas pela filha, era considerado positivo para a confiabilidade dos relatos. Diante disso o jogo foi então entregue às duas para que brincassem em casa. Em relatos futuros, a cliente afirmou ter criado novas regras para jogar e disse que ela e o irmão fizeram bilhetes iguais aos da terapeuta. Disse que o irmão fez um bilhete que dizia "diga uma qualidade do seu irmão" e o "o que você mais gosta no seu irmão", tendo a mãe, relatado que os dois brigaram menos nesses dias.

A mãe contou nessa sessão também que Kissylla estava obedecendo mais na hora de ir tomar banho, que ainda reclamava um pouco, mas fazia o que a mãe havia pedido. Outro momento que, segundo relato da mãe a cliente apresentava melhoras, era na hora de acordar para ir à escola. A mãe disse que estava chamando a filha sem gritar, buscando ser carinhosaA filha pedia mais um tempo, mas depois se levantava. A mãe de Kissylla também disse que a menina não tinha mais chutado as coisas ou batido a porta quando contrariada. Por exemplo, um dia que a levou para brincar na casa de uma colega disse ter ficado feliz, pois quando chamou a filha para ir embora, ela levantou-se e já foi, sendo que antes chorava e não queria ir. A mãe relatou ainda que toda a família estava saindo junto mais vezes para lanchar e fazer outros programas, e que até o padrasto de Kissylla estava brincando mais com ela.

Como o caso apresentava diversos avanços, foi apresentado à mãe um quadro mostrando os comportamentos que Kissylla emitia no início do atendimento e os que ela emitia naquele momento. $\mathrm{Na} 30^{\text {a }}$ sessão então, foi sugerido para a mãe da cliente que o atendimento passasse a ser realizado de 15 em 15 dias, como forma de aumentar sua autonomia com as mudanças da filha e diminuir a dependência da terapeuta. Ao sugerir isso, ela disse: "Você está nos soltando aos poucos né", mas 
concordou Depois foi falado também com a menina. Como a mãe comentou que a filha melhorou, mas que o irmão de Kissylla parecia ter regredido por ter ficado em recuperação no colégio e por estar desobedecendo um pouco mais, optou-se por incluí-lo nas sessões em que a mãe e filha eram atendidas juntas.

\section{Espaçamento das Sessões \\ (da $31^{a}$ a $41^{a}$ sessão)}

Na primeira sessão de espaçamento, a mãe disse que estava alterando sua rotina de uma semana para outra. A terapeuta perguntou o que tinha sido alterado e a mãe respondeu que fazer comidae acordar as crianças, isso ela sempre fazia, mas que ainda tinha dificuldades para brincar com as crianças. A terapeuta perguntou no que ela tinha dificuldade e ela respondeu: "acho que me sinto velha para fazer isso ou que não tem muito proveito para mim, ou mesmo porque estou cansada e daí penso em deixar para outro dia”. A terapeuta perguntou quantas vezes ela conseguiu brincar na semana. A mãe respondeu três e disse que comprou uma corda e um elástico para pular com Kissylla. Então, buscou-se aumentar a discriminação da mãe quanto ao que ela já conseguia, reforçando nesse caso, por exemplo, que ela havia brincado três vezes e que isso era mais do que no atendimento anterior, no qual ela havia brincado duas vezes. E que, nos dias que ela não conseguisse brincar por muito tempo, se conseguisse brincar pelo menos um pouco já seria melhor do que ficar sem brincar.

Na sessão seguinte, foi usado um jogo de dominó para promover a interação com Kissylla, sua mãe e seu irmão. Uma das pedras do jogo encontrava-se marcada, e já tinha sido observado pela terapeuta nas sessões iniciais que a cliente trapaceava quando saía com a mesma. Em duas das jogadas, a cliente manteve o mesmo comportamento (CRB1), porém na terceira vez que isso aconteceu, sem que ninguém perguntasse, ela disse que estava dando para ver a marca na pedra (CRB2). Em outra vez que estavam jogando, o irmão notou que ela saiu com a pedra e disse que ela estava marcando novamente. A terapeuta perguntou se ela estava fazendo isso e ela fez que sim com a cabeça (CRB2). Mesmo tendo emitindo alguns CRBs1 durante a brincadeira, considerou-se avanço o fato da cliente inicialmen- te falar sem ninguém perguntar e depois admitir quando perguntada, o que não acontecia nas etapas iniciais do atendimento. Levou-se também em consideração a presença do irmão nas brincadeiras, que nunca tinha estado presente nas sessões e assim trazia um contexto mais próximo de emissão de comportamentos da cliente fora do ambiente do atendimento.

Ainda na mesma sessão Kissylla disse ter ido três vezes para o cantinho da disciplina nesse período de 15 dias. A mãe disse que usou o cantinho para não bater na filha, pois chegou a jogar um brinquedo e um chinelo na menina antes de usar esse recurso. Segundo a mãe, ela colocou Kissylla no cantinho por ter desprezado e desfeito do padrasto mesmo depois da mãe ter falado com ela para não fazer isso. As outras duas vezes foram na hora do banho, pois Kissylla ficou respondendo a mãe. Quando perguntada quantas vezes tinha brincado com as crianças nessas duas semanas, a mãe falou que uma.Devido a essas dificuldades, a sessão seguinte foi marcada apenas com a mãe na outra semana, ao invés de aguardar 15 dias.

Nesse atendimento extra, buscou-se mostrar para a mãe a relação entre ela não se organizar e ficar sem brincar com as crianças com a indisciplina deles e sua perda de paciência que resultaram em ela acabar batendo novamente. Foi explicado que problemas que a menina apresentava eram reforçados pela atenção da mãe, pois quando a mãe conseguia dedicar mais tempo a eles, ainda que não todos os dias, ela observava diminuição das brigas e desentendimentos. A terapeuta destacou mais uma vez a função dos espaçamentos entre as sessões, mas que para funcionar, ela precisava continuar fazendo sua parte, ou seria melhor voltar a fazer os atendimentos semanalmente. Então, perguntou à mãe como ela achava que os atendimentos deveriam ser, se todas as semanas ou de 15 em 15 dias. Ela respondeu: "Você quem sabe, como você marcar eu venho." (CRB1). A terapeuta então respondeu: "Não, é isso que estou querendo te mostrar. Você precisa se colocar nas situações, não pode deixar que eu decida. Percebe que muitas vezes também deixa que seus filhos decidam o que é para você decidir?" Ela disse: "Puxa é mesmo, faço isso com a Kissylla. Então, quero que seja na semana que vem novamente" (CRB2). 
Na sessão seguinte a mãe ainda relatou dificuldade em brincar com os filhos. O diálogo entre ela e a terapeuta ilustra bem as intervenções realizadas:

Terapeuta: "Você me disse semana passada que estava conseguindo fazer mais ou menos a rotina. No que você tem tido dificuldade?"; Mãe: "é na hora de brincar mesmo"; Terapeuta: "Você conseguiu brincar essa semana?"; Mãe: "Sim, três vezes, de cirandinha, uno e stop"; Terapeuta: "E o que você percebeu de bom nisso?"; Mãe: "Eu me sinto muito antiquada fazendo isso"; Terapeuta: "Entendi, mas o que você vê de bom?"; Mãe: "É que a Kissylla para de ficar andando atrás de mim (ela fala rindo CRB1)"; Terapeuta: "Ela para de andar atrás de você porque você deu atenção a ela. Daqui um tempo ela irá crescer e não precisará tanto da sua atenção, será que não poderá ser você que andará atrás dela?"; Mãe: "É mesmo"; Terapeuta: "nós começamos a fazer o atendimento de 15 em 15 dias porque você e Kissylla tiveram grandes avanços, voltamos essas semanas porque você estava com algumas dificuldades para brincar e isso acontece, mas você percebe que nessa semana que você brincou você mesma me disse que foi mais calma?"; Mãe: “é, também tenho conseguido ter um tempo para mim e isso me deixa mais calma para lidar com as crianças"; Terapeuta: "quando você quer que seja o nosso próximo atendimento?"; Mãe: "na semana que vem, pois Kissylla queria muito vir e não deixei porque você me disse que era só comigo ${ }^{8 ”}$ (CRB2).

$\mathrm{Na}$ última sessão antes do natal de 2012, foi pensado um atendimento diferente, como forma de dar um modelo para a família de como interagir, comemorar e fortalecer a relação entre eles, já que estes estavam sendo os objetivos principais das últimas sessões. Participaram do atendimento a mãe, Kissylla e o irmão mais velho. A sala estava preparada com luzes e árvore de natal, cartaz, mesa com lembrancinhas e lençol no chão. A cliente se aproximou e apenas tocou nos presentes, mas a mãe pediu que ela esperasse para depois e a menina não mexeu mais (CRB2).

A terapeuta buscou fazer uma retrospectiva do que aconteceu com a família naquele ano, pe-

8 Depois da suspensão do espaçamento por dois atendimentos que ocorreram semanalmente, as sessões voltaram a ocorrer de 15 em 15 dias. diu que eles dissessem coisas que gostaram e o que desejavam para o próximo ano. A mãe começou dizendo: "Gostei de ter passado mais tempo com meus filhos, ter conseguido sair mais com eles, ter ido ao museu, no passeio de férias. Espero para o próximo ano que tenha ainda mais união em nossa família”. Kissylla disse que o que mais gostou é que vai ganhar uma bicicleta. Depois foi a vez do irmão e ele disse que gostou porque sua mãe brincou mais com ele, só não gostou de perder para ela no futebol. Kissylla completou: "Mas, o importante é brincar (CRB2)".

Em outro momento da sessão a terapeuta colocou um chapéu de Papai Noel e entregou uma lembrancinha para cada um, depois cada um deveria entregar bombons uns para os outros. A mãe dá início entregando um bombom para Kissylla.Ela disse: "Você é uma boa filha, tem sido mais obediente, foi estudiosa, está seguindo mais as regras e eu te amo", e elas se abraçaram. Entregou depois para o filho e disse: "apesar de não ter estudado tanto esse ano, você é um bom filho e eu te amo." A mãe passou o chapéu para Kissylla que começou pela mãe e disse: "eu te amo" entregou o bombom e se abraçaram. Para o irmão ela disse: "Você implica comigo, mas eu te amo" e então o abraçou. A cliente passou o chapéu para o irmão que começou pela mãe e disse: "Vou dar para a coroa. Você é muito legal e eu te amo" e abraçaram-se. Para a irmã ele disse: "Você é chata, mas brinca comigo mais que a mãe e eu amo você" e abraçaram-se. Apesar de ter sido observado o aumento de demonstrações de afeto entre mãe e filha, foi importante notar que o irmão ainda emitia falas irônicas/agressivas com a mãe e a cliente, tal como elas, quando chegaram no início do atendimento, mostrando não só a melhora no comportamento das duas, mas também a relevância da inclusão do irmão nas etapas finais da terapia.

Depois desse atendimento, a próxima sessão foi realizada um mês e quatro dias depois, devido a novo período de férias na instituição. Na sessão de retorno, foi atendida apenas a mãe, que contou que o filho mais velho conseguiu passar na recuperação escolar e que a cliente ficou novamente no cantinho da disciplina por tê-la respondido. A mãe contou ainda ter batido novamente na menina por ela ter gritado quando pediu para que guardasse seus 
brinquedos. A terapeuta buscou mostrar novamente para a mãe o que ela tinha melhorado e o que ainda precisava modificar, dizendo: "Você tem ido muito bem, melhorou desde que chegou, começou a brincar, percebe que tem uma parcela fundamental nos problemas que Kissylla chegou apresentando e isso de bater é o que falta para melhorarmos. Fico feliz que você confie em mim para me dizer mesmo quando erra em ter batido, acho que você faz isso, pois sabe que não vou te punir e que quero te ajudar. É essa relação que estou tentando ajudar você a ter com Kissylla, para que quando ela errar confie em você e não que fique com medo de apanhar."

Depois perguntou a mãe quanto ao brincar. Ela disse que não foi muito bem, pois saíram bastante e chegavam cansados. Mas que foram na praça, no shopping e ela levou-os para brincar com os amiguinhos. A terapeuta explicou que mais que brincar, o importante era ter tempo com os filhos, e que saindo com eles também lhes dá atenção em momentos que eles não estão fazendo algo que considera errado. A mãe disse também que saiu todos os fins de semana e falou: "Antes eu não saía, agora que meu marido mudou de horário, ele fica em casa, se não quer ir, eu aprendi a ir só com as crianças." Diferentemente da primeira situação que ela bateu na filha, dessa vez a mãe relatou ter dedicado tempo a eles, então não se avaliou como necessário voltar novamente para os atendimentos semanais.

Como as dificuldades da mãe com a filha ainda se relacionavam a comportamentos como tomar banho, arrumar o quarto e guardar os brinquedos, na outra sessão foram levados outros quatro vídeos relacionados com esses assuntos com o objetivo de treinar melhor essas situações. Um deles apresentava o tema "tomar banho" (Castelo rá-tim-bum, 2013), o outro "bater" (Turma da Mônica - Violência Infantil, 2013), o outro "obedecer aos pais” (Turma da Mônica - O Sumiço de Todas as Mães, 2013), e o outro "importância da interação com a criança” (Crescendo e Aprendendo - brinca comigo, 2013). Entre todos o que evocou mais CRB's foi o primeiro, que será descrito a seguir. A terapeuta fingiu ser uma amiga da cliente que está brincando com ela, quando sua mãe a chama para tomar banho. A mãe disse: "Kissylla é hora de tomar banho" (tom de voz mediano, sem gritar, nem ser agressiva, mas também não carinhoso). Kissylla respondeu: "Ah" (depois se levanta e vai). A terapeuta disse que era compreensível que a cliente resmungasse um pouco, pois ela estava brincando. Disse que ficou bom, mas que dava para ela ser um pouco mais carinhosa. Então, a terapeuta deu um modelo brincando com Kissylla e fazendo cócegas. A menina foi tomar banho sem resmungar. A terapeuta pediu então que a mãe tentasse novamente da forma que achasse mais carinhosa. Ela esperou um pouco e disse: "vamos cascãozinho" (CRB1). Depois de um tempo, ela fez carinho na cabeça da filha e disse: "vamos tomar banho minha filhinha linda, a mamãe te ajuda" (CRB2). A menina levantou-se sem resmungar e fingiu ir tomar banho.

$\mathrm{O}$ atendimento seguinte foi feito apenas com a mãe, ela disse que os últimos dias tinham sido bons. Segundo ela: "Só no banho que a Kissylla ainda enrola, mas não foco mais nas coisas pequenas que ela e o irmão fazem. Não me sinto mais irritada. Antes eu achava que todo o problema era Kissylla, que ela estava errada e eu certa. Agora vejo que é preciso decidir algumas coisas por ela e saber que ela não entende as coisas como eu" (CRB2). A terapeuta buscou conferir com a mãe como estava a relação com a filha. A mãe disse que brincou de restaurante com ela, explicou como foi a brincadeira e disse que até o bebê participou. Também contou que foram passear no aeroporto, à casa de uma amiga e saíram para lanchar.

Dada a nova fase de avanços, a terapeuta aproveitou para retomar perguntas a respeito de comportamentos emitidos pela cliente nos primeiros atendimentos, que faziam parte de sua queixa, como quebrar objetos das pessoas ou "desafiar as pessoas com o olhar". A mãe disse "ela nunca mais fez isso, pois está mais calma e não tem nada que a irrite a esse ponto". Ela disse que a menina ainda bate a porta e grita com o irmão, mas que apesar disso, agora quando Kissylla faz algo, ela admite o que fez e completou: "antes era um sacrifício saber quem tinha sido e ela não admitia."

Com base nesses relatos, decidiu-se por espaçar as sessões para 30 dias para se certificar que os resultados seriam mantidos. Ao propor isso à mãe, ela repetiu o que já tinha dito na primeira etapa do espaçamento: "Você está nos largando aos pouquinhos." Depois disse que tudo bem e que, no começo, quando passou para sessões a cada 15 dias, 
Kissylla reclamava e queria vir junto, mas que agora só mandava um beijo para a terapeuta e não ficava pedindo para ir também (atendendo ao objetivo de um espaçamento gradativo dos atendimentos).

Assim, o atendimento seguinte, foi realizado depois de um mês com a mãe, a cliente e o irmão. Foram levados diversos jogos como: ludo, dominó, UNO, jogo da memória, boliche, bingo e também lápis de cor, livros, etc. $\mathrm{O}$ objetivo era deixar a sessão mais livre e que as crianças escolhessem o que quisessem brincar, reforçando a relação familiar e os ganhos já obtidos. Logo no início, a terapeuta observou que ao chamar para o atendimento, Kissylla estava sentada ao lado da mãe e do irmão e só veio até a sala quando foi chamada (CRB2). A terapeuta iniciou a sessão perguntando como todos estavam. O irmão de Kissylla respondeu "está bem legal, a mãe está brincado bastante com a gente." Ele continuou explicando como era a brincadeira da cócega, então disse para a mãe: "vamos mostrar para ela mãe." A família começou a brincar de cócegas. A mãe prendia um dos filhos por vez por entre as pernas e fazia cócegas, enquanto o outro precisava ajudar o irmão a sair.

Assim, após outros atendimentos espaçados, foi entendido que a família estava conseguindo manter os ganhos obtidos e decidiu-se então pela alta. No dia anterior ao atendimento que isso seria proposto, a mãe de Kissylla ligou para a terapeuta e pediu alteração de horário, pois havia conseguido emprego. Isso também foi considerado um grande avanço, tanto pelo ganho de autonomia da mãe que iria começar a trabalhar, quanto por ser a primeira vez em um ano e cinco meses de atendimento que ela pediu uma alteração de horário que fosse melhor para ela, ao invés de simplesmente aceitar o que a terapeuta falava (CRB2).

No último atendimento a mãe contou que as crianças estavam ficando com uma babá, já que ela tinha começado a trabalhar.Disse que todo dia conversava com as crianças, apesar de nem sempre estar brincando. A terapeuta perguntou quantas vezes aproximadamente a família conseguiu interagir no último mês e a mãe disse que só não conseguiu três dias. A terapeuta elogiou o empenho da mãe, que respondeu: "antes tinha muita dificuldade em brincar, mas que agora não fico pensando em deixar para depois". Contou também que brincou com um jogo que o esposo levou do serviço para eles brincarem e que ela levou uma corda para pular junto com os filhos. Também disse que os ajudava nas tarefas, às vezes contava uma história para Kissylla e assistiam a filmes e desenhos juntos.

Diante disso, a terapeuta ressaltou todos os avanços de Kissylla e da mãe, explicando que sempre existem coisas que podemos melhorar, e que crianças sempre podem apresentar um ou outro problema, mas que ela agora estava melhor preparada para lidar como mãe com os filhos, e que estava dando alta para Kissylla. A mãe ficou com lágrimas nos olhos. A terapeuta entendeu que ela estava com dificuldade em demonstrar o que estava sentindo e, com o objetivo de dar um modelo de expressão de sentimentos e por ser de fato o que a terapeuta sentia naquele momento, ela disse a mãe: "também sentirei saudades, Kissylla foi minha primeira cliente e não me esquecerei de sua família, pois foi este atendimento que me fez interessar-me em atender crianças. Sempre que precisar pode contar comigo."

A terapeuta explicou que ainda iria se despedir da cliente e perguntou se poderia fazer uma última visita breve em sua casa para isso. A mãe respondeu que sim e disse o melhor dia e horário para ela (CRB2). Assim, no dia e horário combinado foi feito o último atendimento. Quando a terapeuta chegou, a cliente estava na frente da casa, mas não saiu para a rua como da última vez (CRB2). A terapeuta notou também que a casa estava diferente da última visita: a sala estava com dois sofás a mais, agora havia uma mesa com cadeiras, o quarto de Kissylla tinha uma cama nova e o quarto do irmão mais velho estava com divisória e porta.

Quando a terapeuta explicou que o atendimento seria encerrado, a cliente e a mãe começaram a chorar. Kissylla abraçou a terapeuta, que explicou que não estava indo embora, só estava dizendo que ela não precisava mais de sua ajuda, pois agora tinha uma pessoa muito melhor que ela, sua mãe, para poder brincar e ajudar com tudo que ela precisasse. Disse também que ela estaria sempre à disposição e que poderia ligar sempre que precisasse. Kissylla abraçou novamente a terapeuta, chorou por mais um tempo, depois perguntou se ela queria brincar. A terapeuta, a mãe e as crianças brincaram um pouco de cobra-cega e quando 
notou que a criança e a família estavam melhores a terapeuta disse que iria embora. Kissylla pediu à mãe que trouxesse o presente que tinha escolhido para a terapeuta. Ela entregou então, um brinco e uma carta. Depois agradeceu pela terapeuta tê-la ajudado a assumir seus erros, se dar melhor com sua mãe e não brigarem.

$\mathrm{Na}$ carta Kissylla desenhou duas pessoas, uma com os cabelos amarelos e outra com os cabelos pretos. A terapeuta perguntou quem eram e Kissylla disse: você e eu. A terapeuta perguntou quem era ela, então Kissylla apontou a menina de cabelos negros e cacheados. Kissylla pegou sua bicicleta para mostrar a terapeuta e foi andando junto com a família até o portão. A terapeuta se despediu de todos. Kissylla se despediu e ficou andando de bicicleta.

\section{Discussão}

Através da descrição do caso pôde-se observar como um número variado de brincadeiras realizadas pela terapeuta estabeleceu, gradativamente, o maior seguimento de regras pela cliente. Brincando, Kissylla aprendeu a seguir regras como não trapacear, assumir erros, respeitar a mãe, obedecer para arrumar o quarto ou tomar banho, etc. Além disso, o contato com regras também proporcionou que ela própria formulasse outras regras como a que ela fez sobre "não roubar" durante o jogo de boliche ou autoregras como "o importante é brincar", quando a terapeuta estava perdendo. $\mathrm{O}$ que demonstrou que algumas regras não precisavam ser diretamente ensinadas para que outras fossem formuladas ou seguidas, sendo esse um responder de ordem superior (Catania, 1999).

Assim o comportamento de roubar, queixa inicial trazida pela mãe, foi entendido como resultado do não seguimento generalizado de regras, derivado da dificuldade que a mãe tinha em reforçar comportamentos adequados e ao mesmo tempo colocar limites consistentes. Desta maneira, tratar o roubo seria um retrocesso à modificação do comportamento, pois se daria apenas atenção a queixa e não ao problema, desconsiderando a realização de uma análise funcional apropriada. Assim, $\mathrm{o}$ atendimento seria insuficiente por deixar de fora muitas classes de comportamentos relevantes, além de desconsi- derar a relação com a própria criança. A importância do brincar como ferramenta na mudança do comportamento foi notada durante o atendimento, também porque nas semanas que a mãe relatava ter conseguido dar atenção à criança e brincar com ela, eram também as semanas que a menina obedecia às regras. Ao contrário, nas semanas em que a mãe não tinha reservado esse tempo de interação com a criança, ocorriam comportamentos de desobediência por parte da menina e de bater por parte da mãe. Com isso, podemos notar a importância dos pais na TACI, já que são parte fundamental do ambiente da criança, elas adquirem padrões de comportamento essencialmente através da interação familiar (Gomide, 2004).

Resultados satisfatórios já estavam sendo obtidos com a criança por volta da $20^{\text {a }}$ sessão, porém nesse ponto foi observada a importância de se ampliar o atendimento com a mãe, pois seu padrão de comportamento interferia diretamente na manutenção de alguns comportamentos de Kissylla (dificuldade em colocar regras, em dar afeto e problemas com críticas e autoestima). Tendo isso em vista, a maior participação da mãe, nesse caso, foi uma variável importante nos ganhos obtidos, pois permitiu maior similaridade com o ambiente natural, visto que os comportamentos-problema que eram relatados ou observados na relação mãe e filha puderam ser evocados mais facilmente pela terapeuta na sessão. Ou seja, um dos objetivos do TP hoje é a generalização e manutenção dos ganhos obtidos com a criança, sendo que a ação em comportamentos isolados não se mostra tão eficiente em garantir tais resultados (McMahon, 1996).

As visitas realizadas na casa da cliente também foram importantes como fonte de dados e forma de intervenção. Através da primeira visita foi possível, por exemplo, observar o padrão irônico/agressivo de interação familiar, a dificuldade da mãe em ser consistente no estabelecimento e cumprimento de regras não só com a cliente mas também com seus irmãos e a falta de organização de uma rotina da família que não tinham horário e local adequado para fazer suas refeições, sendo que todos o faziam em frente à televisão. Borges e Oliveira (2007) colocam que o atendimento extra consultório, além de dar maior fidedignidade aos dados, favorece que se compreenda os processos envolvidos nas relações 
entre o comportamento verbal e o não verbal emitido pelos clientes.

Enquanto o ambiente do consultório por vezes limita a atuação do terapeuta ao nível verbal, certas intervenções não verbais como, por exemplo, com a realização de treinos, deveres e atendimentos extra consultório, podem produzir mudanças importantes ao processo terapêutico. Del Prette (2011) discutiu como os treinos em sessão, além de favorecerem mudanças diretas do comportamento, já que estabelecem consequências para o mesmo no momento em que ocorre, também são importantes na formação de regras e autorregras, que igualmente podem controlar o comportamento do cliente posteriormente, fora da sessão. Por exemplo, situações em que a mãe tendia a bater na criança ou mesmo flexibilizar a regra que ela tinha dado, reforçando o padrão de não seguimento pela filha, eram encenadas na sessão oferecendo-se inicialmente modelos de ação, mas gradativamente sendo substituídas por perguntas como: "como vocês acham que poderiam agir em tal situação?", o que por sua vez era acompanhado de verbalizações da cliente e de sua mãe que mostravam exercer controle sobre seus comportamentos fora da sessão.

Esse princípio discutido na FAP, de evocar comportamentos problemáticos em sessão e favorecer o aparecimento de CRBs 2 e CRBs 3, permitiu a melhora no padrão de interação familiar no caso apresentado, já que favoreceu o treino de comportamentos adequados alternativos (Kohlenberg e Tsai, 2001). Porém, é importante notar que durante o treino de situações como a hora do banho ou a hora de acordar, mesmo com todo o envolvimento da criança na atividade, não foram evocadas tantas respostas emocionais de raiva, choro ou fuga, como nas situações em que se encenou mentira ou expressão de sentimentos na sessão. Esse fator leva-nos a considerar o papel dos eventos privados na TACI, sendo esse um dos elementos já discutidos que a diferencia da modificação do comportamento. Com essa mudança, Kissylla, que no início do atendimento não tinha amigos, não dividia os brinquedos, quebrava coisas e gritava quando contrariada, passou a fazer piquenique na escola com os colegas, brigava menos com o irmão, não chorava e continuava a brincar mesmo quando perdia. Além de melhorar sua sociabilidade e afetividade, pôde ser observada também alteração no repertório de autocontrole da criança.

Assim, grande parte das mudanças no comportamento da cliente podem ter se dado pelas brincadeiras realizadas pela terapeuta. Pode-se dizer também que a brincadeira teve função de cunha comportamental, quando, por exemplo, Kissyla aprendeu a seguir as instruções de jogos sem emitir comportamentos como se levantar ou bater na mesa, o que pode ter feito com que seus amigos tendessem a brincar mais com ela, o que por sua vez também alterou a sua relação social com eles, de acordo com seu próprio relato e relato da mãe. Como colocado por Conte e Regra (2000), a inserção da criança no processo terapêutico exigiu que se pensasse em estratégias lúdicas, sendo que outros estudos mostram como não apenas brincadeiras, mas também histórias infantis podem ter o mesmo efeito na formulação e seguimento de instruções (Almeida, 2009; Craveiro, 2009).

Este trabalho buscou demonstrar então, a importância da brincadeira como forma de acessar regras e autorregras que podem estar controlando o comportamento da criança, pois serve como alternativa ao relato verbal, já que a criança geralmente encontra dificuldades em descrever e alterar seu próprio comportamento como no caso de adultos. Assim, a brincadeira pode favorecer a desconstrução de regras disfuncionais e a construção de novas regras melhor adaptadas ao seu ambiente (Gadelha \& Menezes, 2004).

Apesar de não terem sido usados recursos de filmagens ou gravações, buscou-se apresentar durante o texto alguns modelos ou descrições de brincadeiras como forma de auxiliar outros terapeutas na condução de casos semelhantes. Porém, a ausência de registros mais precisos, bem como de um follow up após o término do atendimento, se apresentam como limitações deste estudo, o que pode colocar em dúvida a validade de parte das análises realizadas bem como da real efetividade das intervenções na produção dos efeitos descritos. A esse respeito, Kazdin (1981) diz que, no estudo de caso, problemas relacionados à validade interna não podem ser solucionados da mesma forma que em contexto experimenta,l onde se tem maior grau de controle de variáveis. Nock, Michel e Photos (2007) também apontam como outra limitação do estudo 
de caso a dificuldade na generalização dos resultados alcançados, já que uma intervenção pode produzir um efeito em um individuo, mas não em outro, ou a mesma intervenção pode produzir efeitos diferentes no mesmo individuo.

No entanto, ao longo da história da psicoterapia estudos de casos tem exercido forte influência em pesquisas posteriores e na própria prática clínica. De fato, o terapeuta guia suas análises e intervenções com base em inferências e muitas vezes podem existir hipóteses contrárias suficientemente plausíveis que explicam um mesmo resultado. No entanto, Del Prette (2011) fala da limitação dos estudos de caso como algo que pode ser melhorado com o avanço de pesquisas na área. A existência de variabilidade na análise de casos individuais não é o mesmo que dizer que não é possível se ter algum tipo de previsão ou controle, e essa forma de correção metodológica pode se dar, por exemplo, através de replicações (Matos, 1990). Espera-se, portanto, que esse trabalho sirva como mais um passo na direção de fomentar a realização de novos estudos na área da clínica comportamental infantil. Outros trabalhos que investigarem diretamente, por exemplo, os efeitos de cada brincadeira utilizada pela terapeuta no estabelecimento e manutenção do seguimento de regras em outras crianças, poderiam representar uma importante contribuição para esta área.

\section{Referências}

Albuquerque, L. C. (2001). Definições de regras. Em: H. J. Guilhardi et al. (Orgs.), Sobre comportamento e cognição: Expondo a variabilidade (vol. 7, pp. 132-140). Santo André: ESEtec.

Almeida. C. G. M. (2009). Efeitos de contingências descritas em histórias sobre o comportamento de crianças. (Dissertação de mestrado). Universidade Federal do Pará, Belém, Pará.

Azevedo, M. R. Z. S. \& Moura, C. B. (2000). Estratégias lúdicas para uso em terapia comportamental infantil. Em: R. C. Wielenska, (Org.), Sobre comportamento e cognição: Questionando e ampliando a teoria e as intervenções clínicas em outros contextos. (Vol. 6, pp.163-170). Santo André: ESEtec.

Borges, N. B. \& Oliveira, D. L. (2007). O ambiente natural como fonte de dados para a avaliação inicial e a avaliação de resultados: Suplantando o relato verbal. Em: D. R. Zamignani, R. Kovac \& J. S. Vermes (Orgs.), A clínica de portas abertas: Experiências e fundamentação do acompanhamento terapêutico e da prática clínica em ambiente extraconsultório (pp. 77-100). Santo André: ESEtec.

Castelo Rá Tim Bum. (2013). Ratinho - Meu Pé Meu Querido Pé (Tomando Banho). Retirado de: http://youtube/cTycyMhBPY8.

Catania, A. C. (1999). Aprendizagem: Comportamento, linguagem e cognição. ( $4^{\mathrm{a}}$ ed.; D. G. Souza et al., Trads.). Porto Alegre: ArtMed. (Trabalho original publicado em 1998)

Conte, F. C. S. \& Regra, J. A. G. (2000). A psicoterapia comportamental infantil: Novos aspectos. Em: E. F. M. Silvares (Org.), Estudos de caso em psicologia clínica comportamental infantil (vol. 1, pp. 79-136). São Paulo: Papirus.

Craveiro, C. C. P. (2009). Exposição continuada a regras descritivas sobre o comportamento escolar de crianças. (Dissertação de mestrado). Universidade Federal do Pará, Belém, Pará.

Crescendo e Aprendendo - Brinca Comigo. (2013). Retirado de: http://youtu.be/ewLRorsmLxQ.

Del Prette, G. (2011). Objetivos analíticos comportamentais e estratégias de intervenção nas interações com a criança em sessões de duas renomadas terapeutas infantis. (Tese de doutorado). Universidade de São Paulo, São Paulo.

de Rose, J. C. C. \& Gil, M. S. C. A. (2003). Para uma análise do brincar e de sua função educacionala função educacional do brincar. Em: M. Z. S. Brandão et al. (Orgs.), Sobre comportamento e cognição: a história e os avanços, a seleção por conseqüências em ação (Vol. 11, pp. 373-382). Santo André: ESEtec.

Gadelha, Y. A. \& Menezes I. N. (2004). Estratégias lúdicas na relação terapêutica com crianças na terapia comportamental. Universitas Ciências da Saúde, 2(1), 57-66.

Gil, M. S. C. A. \& de Rose, J. C. (2003). Regras e contingências sociais na brincadeira de crianças. Em: M. Z. S. Brandão et al. (Orgs.), Sobre comportamento e cognição: A história e os avanços, a seleção por consequências em ação (Vol. 11, pp. 383-389). Santo André: ESEtec. 
Gomide, P. I. (2004). Pais presentes, pais ausentes: Regras e limites. Petrópolis: Vozes.

Guedes, M. L. (1993). Equívocos da terapia comportamental. Temas em Psicologia, 1(2), 81-85.

Guilhardi, H. J. (2002). Auto-estima, autoconfiança e responsabilidade. Em: M. Z. S. Brandão, F. C. S. Conte \& S. M. B. Mezzaroba (Orgs.), Comportamento humano: Tudo (ou quase tudo) que você precisa saber para viver melhor (pp. 1-29). Santo André: ESEtec.

Kazdin, A. E. (1981) Drawing valid inferences from case studies. Journal of Consulting and Clinical Psychology, 49(2), 183-192.

Kohlenberg, R. J. \& Tsai, M. (2001). Psicoterapia analítica funcional: Criando relações terapêuticas intensas e curativas. ( $1^{\text {a }}$ Ed.; R. R. Kerbauy et al., Trads.). Santo André: ESEtec. (Trabalho original publicado em 1991).

Matos, M. A. (1990). Controle experimental e controle estatístico: A filosofia do caso único na pesquisa comportamental. Ciência e Cultura, 42, 585-592.

McMahon, Robert J. (1996). Treinamento de pais. Em: V. E. Caballo (Org.), Manual de técnicas de terapia e modificação do comportamento (pp. 399-422). São Paulo: Livraria. Santos.

Meyer, S. B. \& Torres, I. (2003). O brinquedo como instrumento auxiliar para a análise funcional em terapia comportamental infantil. Interação em Psicologia, 7(1), 55-63.

Moura, C. B. \& Venturelli, M. B. (2004). Direcionamentos para a condução do processo terapêutico comportamental com crianças. Revista Brasileira de Terapia Comportamental e Cognitiva, 6(1), 17-30.

Nalin, J. A. R. (1993). O uso da fantasia como instrumento na psicoterapia infantil. Temas em Psicologia, 1(2), 47-56.

Nico, Y. C. \& Thomaz, C. R. C. (2007). Quando o verbal é insuficiente: Possibilidades e limites da atuação clínica dentro e fora do consultório. Em D. R. Zamignani, R. Kovac \& J. S. Vermes (Orgs.), A clínica de portas abertas (pp. 47-75). Santo André: ESEtec.

Nock, M. K., Michel, B. D. \& Photos, V. I. (2007). Single-case research designs. Em D. Mckay (Org.), Handbook of research methods in abnormal and clinical psychology (pp. 337-350).
Thousand Oaks, Ca: Sage.

Regra, J. A. G. (2000). Formas de trabalho na psicoterapia infantil: Mudanças ocorridas e novas direções. Revista Brasileira de Terapia Comportamental e Cognitiva, 2, 79-101.

Rosales-Ruiz, J. \& Baer, D. M. (1997). Behavioral cusps: A developmental and pragmatic concept for behavior analysis. Journal of Applied Behavioral Analysis, 30(3), 533-544.

Souza, M. A. O. (2007). Análise funcional e intervenção na clínica infantil: Um estudo de caso. Em M. R. M. Santos \& E. N. P. Cillo (Orgs.), Ciência do comportamento: Conhecer e avançar (pp.109-122) Santo André: ESEtec.

SBT do Brasil. (2010a). Super Nanny. Retirado de: http://youtu.be/x7N015NkLx8.

SBT do Brasil. (2010b). Super Nanny. Retirado de: http://youtu.be/31e6mwlrias.

Skinner, B. F. (1966). An operant analysis of problem solving. Em: B. Kleinmuntz, (Org.). Problem solving: Research, method, and theory (pp. 225-257). New York: Wiley.

Turma da Mônica - O Sumiço De Todas As Mães. (2013). Retirado de: http://youtu.be/ jF0V8hfxrek.

Turma da Mônica - Violência Infantil. (2013). Retirado de: http://youtu.be/Xkst5Qo5Kg.

\section{Informações do Artigo}

\section{Histórico do artigo:}

Submetido em: 08/05/2014

Primeira decisão editorial: 08/09/2014

Segunda decisão editorial: 13/11/2014

Aceito em: 17/12/2014 